\title{
Micropropagation of Cyrtopodium paludicolum (Orchidaceae) from root tip explants
}

\section{Dayana Rotili Nunes Picolotto ${ }^{1}$, Vespasiano Borges de Paiva Neto $^{2^{*}}$, Fábio de Barros ${ }^{3}$, Daly Roxana Castro Padilha ${ }^{1}$, Ana Cláudia Ferreira da $\mathrm{Cruz}^{4}$ and Wagner Campos Otoni ${ }^{4}$}

\begin{abstract}
An efficient protocol for in vitro plant propagation of Cyrtopodium paludicolum has been developed using root tips dissected from well-developed seedlings. Root tips were cultured on Knudson medium supplemented with $\alpha$-naphthaleneacetic acid (NAA), and/or thidiazuron (TDZ). TDZ did not induce protocorm-like bodies (PLBS) in the NAA absence, indicating phytoregulators synergistic effect. Medium supplemented with 1.34 $\mu$ M NAA and 2.27 $\mu M$ TDZ resulted in better response on PBLs, and subsequent shoot differentiation (55.25 shoots per explant), and in better rooting number and root length responses, favoring acclimatization with $90 \%$ of survived plants. However, the medium supplemented with only NAA $(1.34 \mu \mathrm{M})$ resulted in 33.50 shoots per explant. Histological sections confirmed that only one PLB was induced per responsive root tip, and it showed numerous dispersed and extended meristemoids, or division centers that originated new PBLS. Additionally, this protocol could be an excellent model to study molecular aspects of root to shoot conversion.
\end{abstract}

Key words: Protocorm-like bodies, thidiazuron, $\alpha$-naphthaleneacetic acid, germination.

\section{INTRODUCTION}

The genus Cyrtopodium (Orchidaceae) is widely distributed in tropical and subtropical countries of Central and South America (Menezes 2000), and there are approximately 39 species of Cyrtopodium distributed in Brazil (Barros et al. 2013). The generic name Cyrtopodium means "curved little foot" due to the shape of the column in the center of the flower (Guo et al. 2010). Cyrtopodium paludicolum is a terrestrial orchid species usually found in permanently wet soils, with thick and elongated pseudobulbs, resulting in considerable size of the species (Barros et al. 2013). Due its vegetative beauty and exuberant inflorescences (large yellow flowers on long stems, which can easily exceed two meters in height), $C$. paludicolum has been a frequent target for the local orchids collectors, as observed in visits to private collections and in conversations with farmers who cultivate the plants. Its natural propagation occurs mainly by means of seed germination. However, the natural propagation of the native species is hindered by the intensive collection from the wild, and is severely threatened by agricultural expansion in the Brazilian Savanna, which consequently reduces the appropriated areas of natural occurrence of the species. Zeng et al. (2013) and Rodrigues et al. (2015) claim that asymbiotic germination and tissue culture can provide useful means for conservation and commercial propagation of tropical
Crop Breeding and Applied Biotechnology 17: 191-197, 2017 Brazilian Society of Plant Breeding. Printed in Brazil http://dx.doi.org/10.1590/198470332017v17n3a30
$*$ Corresponding author:
E-mail: vespasiano.paiva@univasf.edu.br

Received: 04 November 2015 Accepted: 14 October 2016

${ }^{1}$ Universidade Federal de Mato Grosso do Sul, Campus de Chapadão do Sul, CP 112, 79.560-000, Chapadão do Sul, MS, Brazil 2 Universidade Federal do Vale do São Francisco, Campus de Ciências Agrárias, Rodovia BR 407, km 119, Lote 543, PSNC, s/n, C1, 56.300-990, Petrolina, PE, Brazil

${ }^{3}$ Instituto de Botânica, Núcleo de Pesquisa Orquidário do Estado, CP 68041, 04.045-972, São Paulo, SP, Brasil ${ }^{4}$ Universidade Federal de Viçosa, Instituto de Biotecnologia Aplicada à Agropecuária (BIOAGRO), Laboratório de Cultura de Tecidos, Campus Universitário, Avenida Peter Henry Rolfs, s/n, 36.570-900, Viçosa, MG, Brazil, 
orchid species critically endangered.

No report on the in vitro culture of $C$. paludiculum has been found in the literature. However, it was possible to find information on other species of the Cyrtopodium genus, such as C. paranaense (Guo et al. 2010) and C. brandonianum (Flachsland et al. 2011). Since orchids are outbreeders, seeds germination as propagation strategy results in obtaining of highly heterozygous plants. Thus, protocols that provide clonal multiplication from different vegetative explants are necessary (Chugh et al. 2009). Several explants have been used aiming at clonal propagation of orchids, such as root and stem meristems, inflorescence axis, flower bud and leaf apex (Colli and Kerbauy 1993, Chen and Chang 2006, Martin and Madassery 2006, Chugh et al. 2009, Mulgund et al. 2011). Although orchid micropropagation has shown great advances in the recent years, the widespread use of in vitro propagation is still limited by problems such as exudation of phenolic compounds from explants isolated from mature plants, somaclonal variation, and transplantation to the field (Chugh et al. 2009).

The use of root has not been considered as explant source for a great number of species, and according to Peterson (1975), root meristem consists of highly determinate cells that have limited morphogenic competence for bud formation. However, bud regeneration in root apices has been reported for some orchid species in in vitro conditions. Ever since, root tips have been effectively used for the induction of shoot buds and protocorm-like bodies (PBLs) of many orchids genera, such as Vanda (Park et al. 2003), Oncidium (Wu et al. 2004), Doritaenopsis (Lang and Hang 2006), Catasetum (Kerbauy 1984a), and Cyrtopodium (Guo et al. 2010, Flachsland et al. 2011). In all cases, the addition of at least one plant growth regulator to the induction medium was necessary.

Plant growth regulators are widely used in micropropagation of orchids, as well as the concentrations of these regulators, which may vary, for instance, according to the explants and plant species. Guo et al. (2010) and Flachsland et al. (2011) reported great success in the root-to-shoot conversion, resulting in PLBs with the addition of cytokinins thidiazuron (TDZ), 6-benzyladenine (BA) and zeatin, isolated or in combination with auxin (indol-3acetic acid), to the culture medium. Lee et al. (2013) claimed that PLBs are important in orchid micropropagation and outwardly resemble to somatic embryos in form and development. Recently, PBLs have been used to obtain synthetic seeds (Mohanty et al. 2013), cryopreservation (Silva 2013, Gogoi et al. 2013) of different orchids species.

The present study aims to assess the competence of the excised root tip of $C$. paludicolum to produce PBLs, and the influence of plant growth regulators $\alpha$-Naphthalene Acetic Acid (NAA) and TDZ over this morphogenic process. In addition, tissue culture is presented as a mean to face threats of genetic diversity, and therefore offer alternative strategies for conservation of native plant species and biodiversity.

\section{MATERIAL AND METHODS}

\section{Root tip explants}

C. paludicolum seedlings with 120 days obtained from asymbiotic germination in Knudson medium (Knudson 1946) were used as explants source. Root tips (average $10 \mathrm{~mm}$ in length) were excised and used as plant material.

\section{Induction medium}

Root tips were placed on glass flasks $\left(250 \mathrm{~cm}^{3}\right)$ containing $40 \mathrm{~mL}$ of previously autoclaved Knudson medium supplemented with $58.43 \mathrm{mM}$ sucrose, NAA $(0,1.34,2.68 \mu \mathrm{M})$ in combination with TDZ $(0,2.27,4.54 \mu \mathrm{M})$, solidified with $0.4 \%$ agar (HiMedia ${ }^{\circ}$ ). The $\mathrm{pH}$ was adjusted to 5.8 before autoclaving at $1.1 \mathrm{~kg} \mathrm{~cm}^{-2}$ and $121^{\circ} \mathrm{C}$ for 20 minutes. Plant growth regulators were filter-sterilized using sterile PES Syringe Filters $\left(0.22 \mu \mathrm{m}\right.$, TPP $\left.{ }^{\circ}\right)$ after the autoclaving process of the medium. Flasks were sealed using transparent polyvinylchloride plastic film (Dispafilm do Brasil Ltda). Cultures were maintained in a growth room at $27 \pm 2{ }^{\circ} \mathrm{C}$ under 16 -h photoperiod and $36 \mu \mathrm{mol} \mathrm{m}^{-2} \mathrm{~s}^{-1}$ irradiance.

\section{Anatomical studies}

Root tip samples were collected during culture and fixed in a solution containing formalin, acetic acid, and $50 \%$ ethyl alcohol ( $5: 5: 90$ parts, respectively). Fixed samples were dehydrated in a graded ethanol series and embedded in methacrylate (Historesin, Leica Instruments, Germany). Cross and longitudinal sections ( $5-\mu \mathrm{m}$ thick) were obtained using 
an automatic rotary microtome (RM 2155, Leica Microsystems Inc., USA) and stained with toluidine blue (O'Brien and McCully 1981). Samples were mounted in Permount on glass slides. Photographs were taken using a light microscope (Olympus AX70TRF; Olympus Optical, Japan) equipped with a digital camera (Spot Insight Color 3.2.0; Diagnostic Instruments Inc., USA).

\section{Acclimatization}

After the micropropagation stage, fifty vitroplants resulted from $1.34 \mu \mathrm{M}$ NAA and $2.27 \mu \mathrm{M}$ TDZ treatment were used to evaluate plant acclimatization. Vitroplants were individually placed in black plastic pots $(7 \mathrm{~cm}$ height $\times 7 \mathrm{~cm}$ diameter) containing Plantmax substrate. Pots were placed on benches and kept for 90 days in a greenhouse, with intermittent irrigation system, comprised of microsprinklers, activated by a timer, with two daily irrigation cycles of five minutes each. Plants received foliar fertilizer application (Nipokan ${ }^{\circ}$ ) at weekly intervals according to the manufacturer's recommendation $(75 \mathrm{~mL} / 100 \mathrm{~L}$ ). After the acclimatization period, plant survival percentage was evaluated.

\section{Statistical analysis}

The experiment was arranged in a $3 \times 3$ factorial completely randomized design with three NAA concentrations $(0$, $1.34,2.68 \mu \mathrm{M})$ and three TDZ concentrations $(0,2.27,4.54 \mu \mathrm{M})$. Each replication consisted of one flask containing three root tip explants, with four replications per each treatment.

Morphogenetic responses of root tip explants were assessed by recording the number and length of obtained shoots; number and length of roots; and percentage of survivor explants, at 120 days of culture. Count data were transformed to $x+0.5$, and the percentage data were transformed to $\arcsin x$. Data were analyzed using analysis of variance (ANOVA), followed by the Tukey's test for comparison of means at $5 \%$ probability level. The statistical package SISVAR (Ferreira 2011) was used for statistical analysis.

\section{RESULTS}

Throughout in vitro culture of $C$. paludicolum seedlings on Knudson medium, eventual direct PLB formation was observed in the apical region (Figures $1 \mathrm{~A}, \mathrm{~B}$ ), and in non-apical root regions, although the latter was less frequent (Figure 1C). In both cases, no plant growth regulators (PGR) were added to the Knudson medium; however, in these cases,

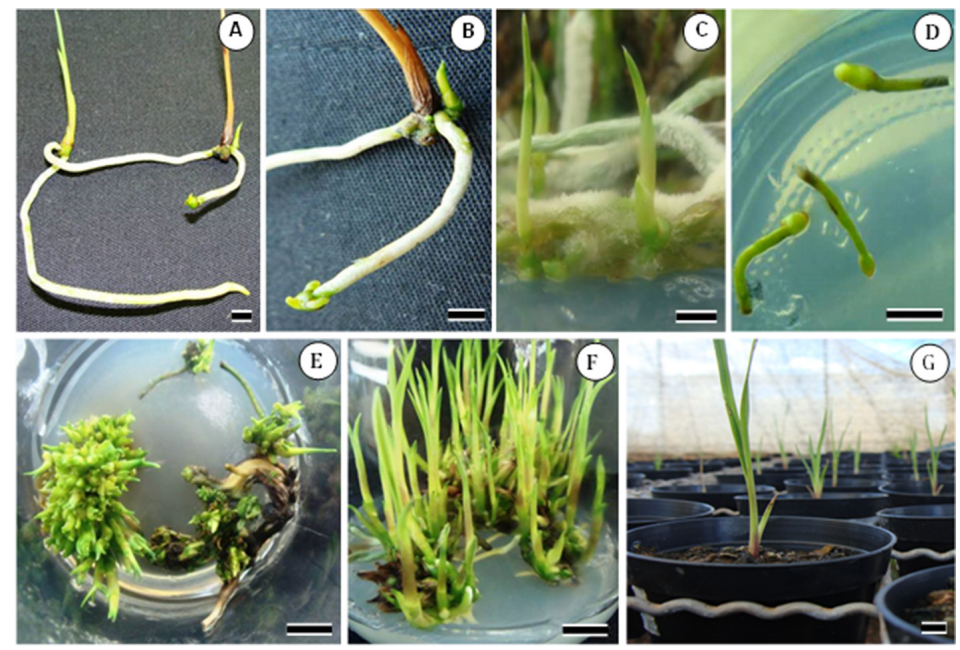

Figure 1. Different stages of protocorm-like body (PLB) development from intact root tip (A, B, C) of Cyrtopodium paludicolum cultivated in Knudson medium without plant growth regulators, and from segmented root tip cultivated in Knudson medium with 1.34 $\mu \mathrm{M}$ NAA and $2.27 \mu \mathrm{M}$ TDZ (D, E, F). (A) PLB formed from the root tip of aseptically grown seedling; (B) detail of a plantlet from a root tip-derived PLB still connected to the maternal plant; $(C)$ well-developed plantlet obtained from PLB originated in the non-apical root tissue yet connected to maternal plant; (D) segmented root tip showing initial morphological alterations; (E) multishoots resulted from root tip derived PLB; (F) elongated shoots from root tip derived PLB; (G) Acclimatized plants. Bars $=10 \mathrm{~mm}$. 
PLBs were originated only when root was still attached to donor plants (Figures 1A, C). Additionally, PBLs originated in the process were capable of generating plantlets morphologically similar to donor plants. However, this phenomenon occurred in very low frequencies in excised root tips. Moreover, $91.75 \%$ (Table 2) of root tips explants died when cultured in plant growth regulators (PGR) free-medium, underscoring the role of the intact $C$. paludicolum plant for PLB induction without PGR.

Different concentrations of NAA and TDZ added to the basal Knudson medium were tested for their ability to induce PLB on excised root tips. Both NAA and TDZ were efficient in forming PLB, and significant interaction was observed between the two PGRs (Table 1), revealed by analysis of variance. When NAA was used alone, root-tip explants with PLB formation were obtained in both tested concentrations (1.34 and $2.68 \mu \mathrm{M})$ (Table 2). Contrarily, no improvement on PLB induction was verified when TDZ was tested alone. However, when NAA and TDZ were added together, they greatly enhanced PLB formation. Treatment containing 1.34 $\mu \mathrm{M}$ NAA combined with $2.27 \mu \mathrm{M}$ TDZ resulted in excised root tips with higher PLBs number (Table 1, Figures 1D, F). Additionally, PBLs maintained in this PGRs combination resulted in plantlets with higher shoot length, number of roots number and length. These data suggest a synergistic effect between NAA and TDZ (Table 2), as confirmed by the statistical analyses (Table 1).

After inoculation in the presence of NAA and/or TDZ, C. paludicolum root tip explants presented an elongation stage. After that, approximately $71.97 \%$ root tip explants survived and formed a clear globular structure at the apical root

Table 1. Summary of the analysis of variance of shoot length, number of roots, longest root length, number of shoots, and survival (\%) of Cyrtopodium paludicolum vitroplants derived from excised root tip explants cultivated in different combinations of plant growth regulators thidiazuron (TDZ) and $\alpha$-naphtaleneacetic acid (NAA)

\begin{tabular}{|c|c|c|c|c|c|c|}
\hline \multirow{3}{*}{ Source } & \multirow{3}{*}{ df } & \multicolumn{5}{|c|}{ Mean Square } \\
\hline & & \multirow{2}{*}{ Explants survival (\%) } & \multicolumn{2}{|c|}{ Shoot } & \multicolumn{2}{|c|}{ Root } \\
\hline & & & number & length & length & number \\
\hline NAA & 2 & $2264.5^{*}$ & $3345.0^{* *}$ & $16.9 * *$ & $7.4^{* *}$ & $67.0^{* *}$ \\
\hline TDZ*NAA & 4 & $5940.5^{* *}$ & $572.3^{* *}$ & $3.1^{* *}$ & $3.6^{* *}$ & $6.9^{*}$ \\
\hline Error & 27 & 759.1 & 24.9 & 0.4 & 0.9 & 2.3 \\
\hline
\end{tabular}

* Significantly different at $\mathrm{P} \leq 0.05$; * Significantly different at $\mathrm{P} \leq 0.001$.

Table 2. Effects of concentrations of $\alpha$-naphtaleneacetic acid (NAA) and thidiazuron (TDZ) on the formation of protocorm-like bodies (PLBs) from excised root tip of Cyrtopodium paludicolum maintained in Knudson medium for 120 days

\begin{tabular}{|c|c|c|c|c|}
\hline \multirow{2}{*}{ Parameters } & \multirow{2}{*}{ NAA $(\mu \mathrm{M})$} & \multicolumn{3}{|c|}{ TDZ $(\mu \mathrm{M})$} \\
\hline & & 0.00 & 2.27 & 4.54 \\
\hline & 0.00 & $8.25 \mathrm{Bb}$ & $75.25 \mathrm{Aa}$ & $91.75 \mathrm{Aa}$ \\
\hline \multirow[t]{3}{*}{ Explant survival (\%) } & 1.34 & $91.75 \mathrm{Aa}$ & $66.75 \mathrm{Aab}$ & $83.50 \mathrm{Aa}$ \\
\hline & 2.68 & $91.75 \mathrm{Aa}$ & $25.00 \mathrm{Bb}$ & $50.00 \mathrm{ABa}$ \\
\hline & 0.00 & $0.50 \mathrm{Ab}$ & $4.75 \mathrm{Ab}$ & $1.25 \mathrm{Ab}$ \\
\hline \multirow[t]{2}{*}{ Number of shoots } & 1.34 & $33.50 \mathrm{Ba}$ & $55.25 \mathrm{Aa}$ & $16.75 \mathrm{Ca}$ \\
\hline & 0.00 & $2.50 \mathrm{Ab}$ & $12.50 \mathrm{Ab}$ & $2.50 \mathrm{Ab}$ \\
\hline \multirow[t]{3}{*}{ Shoot length (mm) } & 1.34 & $17.50 \mathrm{Ba}$ & $42.50 \mathrm{Aa}$ & $22.50 \mathrm{Ba}$ \\
\hline & 2.68 & $15.00 \mathrm{Aa}$ & $5.00 \mathrm{Ab}$ & $5.00 \mathrm{Ab}$ \\
\hline & 0.00 & $0.25 \mathrm{Aa}$ & $1.50 \mathrm{Ab}$ & $1.50 \mathrm{Ab}$ \\
\hline Number of roots & 1.34 & $2.25 \mathrm{Ba}$ & $7.25 \mathrm{Aa}$ & 4.75 $\mathrm{ABa}$ \\
\hline Root length (mm) & 2.68 & $2.50 \mathrm{Aa}$ & $2.50 \mathrm{Ab}$ & $10.00 \mathrm{Ab}$ \\
\hline
\end{tabular}

Means followed by the same uppercase letter in different TDZ concentrations (line) are not significantly different according to Tukey test ( $\mathrm{p} \leq 0.05$ ). Means followed by the same lowercase letter on NAA concentration (column) are not significantly different according to Tukey test ( $p \leq 0.05)$ 
region (Figure 1D), and evolved into a primary PLB (Figures 2A, B). Contrarily, medium devoid of NAA and TDZ resulted in a low frequency of root tip explants survival (8.25\%) (Table 2).

The histological details of conversion of root to shoot meristem, and subsequent PBLs proliferation were observed (Figure 3). A single PLB was induced per responsive root tip (Figure 2A). Histological sections showed numerous and dispersed meristemoids or division centers (Figures 2B, D) originated from intense cellular division, primarily in the procambium and ground meristem cells, resulting in intense morphological modifications that generally occur after 40 days. Thus, primary PLB resulted from disconnected root tip (Figures 1D, 2A), and many secondary PLBs resulted from the primary one (Figures 1E, 1F, 2B, 2D), mainly in the segmented root apices cultured in Knudson medium containing 1.34 $\mu \mathrm{M}$ NAA and 2.27 $\mu \mathrm{M}$ TDZ. The cells of the earliest recognizable meristemoids or division centers were small, containing densely staining cytoplasm, and large nuclei centrally located (Figure 2D). These cells stained intensely with toluidine blue, which indicated high levels of DNA and RNA, which is typical of cell division.

Vitroplants resulted from $1.34 \mu \mathrm{M}$ NAA and $2.27 \mu \mathrm{M}$ TDZ treatment (Figure 1) were morphologically similar to seedderived plants, and forty-five plants (90\%) survived after acclimatization stage (Figure 1G).

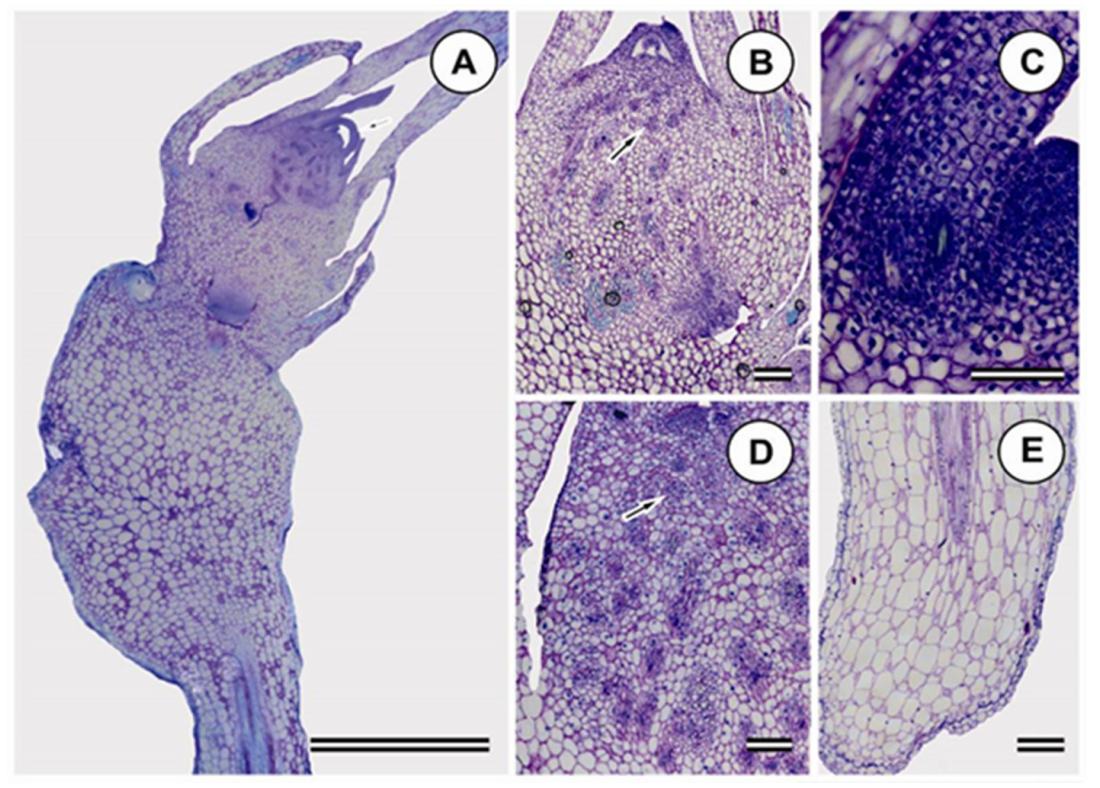

Figure 2. Longitudinal histological sections of the excised root tip of Cyrtopodium paludicolum during protocorm-like body (PLB) formation in Knudson medium supplemented with $1.34 \mu \mathrm{M}$ NAA and $2.27 \mu \mathrm{M}$ TDZ. (A) root to shoot (PLB) conversion, showing leaf primordia (arrow); (B) detail of intense cell division (arrow) in the parenchyma cells of the shoot derived from PLB root tip; (C) detail of the leaf primordia showing intense cell division; (D) detail of meristemoids resulting from cell division in the parenchyma cells (arrow); (E) Longitudinal section of root apex used as the typical explants, showing a root tip. Bars: $A=0.5 \mathrm{~cm}$ and $B, C, D, E=0.1 \mathrm{~cm}$.

\section{DISCUSSIONS}

PLBs and their subsequent growth and development from non-apical regions of the intact root in flask-grown seedlings using free-PGR medium, as reported here with C. paludicolum, were also observed for C. paranaense by Guo et al. (2010). According to these authors, anatomical sections clearly revealed that PLBs were originated from the external cells of the root central stele, protruding through the parenchymal cortical cells and velamen.

When roots were excised and segmented, the beneficial effects of cytokinin, isolated or in combination with auxin during in vitro plant propagation, as reported here, are in agreement with the results obtained in other genera of orchid, such as Cyrtopodium (Flachsland et al. 2011), Oncidium (Mayer et al. 2010), Dendrobium (Sujjaritthurakarn and Kanchanapoom 2011), Xenikophyton (Mulgund et al. 2011), Vanilla (Giridhar and Ravishankar 2004) and Aerides (Devi et al. 2013). Different PGRs have been reported to enhance PLB induction from the excised root tips of several orchid 
species (Kerbauy 1984b, Sánchez 1988, Park et al. 2003), and depending on their concentrations, Auxins were more effective in the induction of PLBs from root tips than cytokinins. In this experiment, the medium containing only NAA was able to induce PLBs from excised root tips of $C$. paludicolum; however, the same did not happen when it contained only TDZ. Conversely, in Catasetum fimbriatum and Catasetum pileatum, excised root apices formed high percentages of PLBs in culture medium without PGRs (Kraus and Monteiro 1989, Colli and Kerbauy 1993). This indicates that the requirement for PGR in medium for root tip PLB induction is species- or genus-dependent, considering that Guo et al. (2010) and Flachsland et al. (2011) found similar results for another Cyrtopodium species, named C. paranaense and C. Brandonianum, respectively.

The best Auxin and cytokinin combination for C. paludicolum (1.34 $\mu \mathrm{M}$ NAA and $2.27 \mu \mathrm{M}$ TDZ) were similar to those used by other authors in equivalent experiments (for instance, $0.5 \mathrm{mg} \mathrm{L}^{-1} \mathrm{TDZ}$ (Flachsland et al. 2011), $0.5 \mathrm{mg} \mathrm{L}^{-1} \mathrm{NAA}^{-1}$ and $1 \mathrm{mg} \mathrm{L}^{-1}$ BAP (Bellaver et al. 2015), $10.2 \mathrm{mM}$ indole-3-acetic acid (IAA) and $9.0 \mathrm{mM}$ TDZ (Guo et al. 2010)). However, the number of shoots per explant obtained in this study was higher than all cited protocols, indicating that the present protocol is well adjusted in relation to PLBs induction. Differently from the results showed by Flachsland et al. (2011), which proposed the necessity to obtain root induction in the $C$. brandonianum PBLs, the present protocol obtained a great number of roots during the development of $C$. paludicolum PBLs, making unnecessary the use of root induction medium, which reinforces the efficiency of the present protocol. Therefore, the auxin and cytokinin balance showed in this study was apparently benefic to PBLs induction and development.

Despite the poor morphogenetic ability of root apical cells of higher plants, including Orchidaceae family, the usefulness of root explants for in vitro propagation purposes is due to their continuous availability, low oxidation rate, and to their ability of being explanted (Chugh et al. 2009). In relation to $C$. paludicolum, roots can be obtained during the entire year, unlike leaves, which are abscised during the drought season, a common behavior in many orchid species found in the Brazilian savannah. In addition, the leaves can be lost by herbivory.

According to Guo et al. (2010) the inhibition of root growth and meristematic cell proliferation in the root apical region is very important for conversion of root tip in PLB in C. paranaense. Further differentiation of these PLBs proceeded normally into plantlets, as observed in the present experiment with C. paludicolum (Figure 2B, C). The root apex region of in vitro C. paludicolum has similar histological traits to those of terrestrial orchids, especially to the root anatomy described for C. paranaense (Guo et al. 2010), presenting several cell layers (Figure 2E), with the primary meristems, including the procambium. The globular expansion increased in size as a result of division and enlargement to become a PLB, as described for C. paranaense by Guo et al. (2010), especially involving the parenchyma cells from root donor tissues. The PLB formation from root tips in C. paludicolum, particularly the existence of vascular connections between early PLBs and explants, is different from the developmental patterns of single cell-originated somatic embryo in other orchids (Kerbauy 1984b, Park et al. 2003) and similar to that in C. paranaense (Guo et al. 2010) and in C. brandonianum (Flachsland et al. 2011).

The success in the acclimatization stage assured the efficiency of this micropropagation protocol. Plants hydration was a constant care during the acclimatization stage, in order to ensure high humidity, since $C$. paludicolum is usually found in flooded areas. Rodrigues et al. (2015) obtained up to $90 \%$ of acclimatization success with Cyrtopodium saintlegerianum. Other authors who obtained vitroplants of the Cyrtopodium genus do not report acclimatization data, such as Guo et al. (2010), Flachsland et al. (2011) and Bellaver et al. (2015).

The present micropropagation protocol is an efficient method to obtain a great number of $C$. paludicolum plants using PLBs originated from excised root tips cultivated in Knudson medium added with 1.34 $\mu$ M NAA and 2.27 $\mu$ M TDZ. These results clearly indicate that asexual PLBs initiated from root tips resulted in regular $C$. paludicolum plants.

\section{ACKNOWLEDGEMENTS}

The authors thank the Fundação de Apoio ao Desenvolvimento do Ensino, Ciência e Tecnologia do Estado de Mato Grosso do Sul (FUNDECT), and the Conselho Nacional de Desenvolvimento Científico e Tecnológico (CNPq) for financial support. 


\section{REFERENCES}

Barros F, Vinhos F, Rodrigues VT, Barberena FFVA, Fraga CN, Pessoa E M, Forster W and Menini Neto L (2013) Orchidaceae. In Lista de espécies da flora do Brasil. Jardim Botânico, Rio de Janeiro. Available at <http://floradobrasil.jbrj.gov.br/jabot/floradobrasil/FB11443> Accessed on April 6, 2015.

Bellaver LA, Kato KMM, Buttini S, Antonietti D, Galli S and Stefanello $S$ (2015) Regeneração in vitro de Cyrtopodium paranaense Schltr (Orchidaceae) a partir de regiões meristemáticas. Revista Brasileira de Energias Renováveis 4: 100-109.

Chen JT and Chang WC (2006) Direct somatic embryogenesis and plant regeneration from leaf explants of Phalaenopsis amabilis. Plant Biology 50: 169-173.

Chugh S, Guha S and Rao IU (2009) Micropropagation of orchids: a review on the potential of different explants. Scientia Horticulturae 122: $507-520$.

Colli S and Kerbauy GB (1993) Direct root tip conversion of Catasetum into protocorm-like bodies - Effects of auxin and cytokinin. Plant Cell, Tissue and Organ Culture 33: 39-44

Devi HS, Devi SI and Singh TD (2013) High frequency plant regeneration system of Aerides odorata Lour. through foliar and shoot tip culture. Notulae Botanicae Horti Agrobotanici 41: 169-176.

Ferreira DF (2011) Sisvar: a computer statistical analysis system. Ciência e Agrotecnologia 35: 1039-1042.

Flachsland E, Terada G, Fernández JM, Medina R, Schinini A, Rey H and Mroginski L (2011) Plant regeneration from root-tip culture of Cyrtopodium brandonianum barb. rodr. (Orchidaceae). Propagation of Ornamental Plants 11: 184-188.

Giridhar P and Ravishankar GA (2004) Efficient micropropagation of Vanilla planifolia Andr under influence of thidiazuron, zeatin and coconut milk. Indian Journal of Biotecnology 3: 113-118.

Gogoi K, Kumaria S and Tandon P (2013) Cryopreservation of Cymbidium eburneum Lindl. and C. hookerianum Rchb. f., two threatened and vulnerable orchids via encapsulation-dehydration. In Vitro Cellular and Developmental Biology Plant 49: 248-254.

Guo WL, Chang YCA and Kao CY (2010) Protocorm-like bodies initiation from root tips of Cyrtopodium paranaense (Orchidaceae). Hortscience 45: 1365-1368.

Kerbauy GB (1984a) Regeneration of protocorm-like bodies through in vitro culture of root tips of Catasetum (Orchidaceae). Zeitschrift für Pflanzenphysiologie 113: 287-291.

Kerbauy GB (1984b) Plant regeneration of Oncidium varicosum (Orchidaceae) by means of root tip culture. Plant Cell Reports 3: 27-29

Knudson LA (1946) New nutrient solution for the germination of orchid seeds. American Orchid Society Bulletin 14: 214-217.

Kraus JE and Monteiro WR (1989) Formation of protocorm-like bodies from root apices of Catasetum pileatum (Orchidaceae) cultivated in vitro: I. Morphological aspects. Annals of Botany 64: 491-498.

Lang NT and Hang NT (2006) Using biotechnological approaches for Vanda orchid improvement. Omonrice 14: 140-143.

Lee YI, Hsu ST and Yeung EC (2013) Orchid protocorm-like bodies are somatic embryos. American Journal of Botanic 100: 2121-2131

Martin KP and Madassery JP (2006) Rapid in vitro propagation of Dendrobium hybrids through direct shoot formation from foliar explants and protocorm like bodies. Scientia Horticulturae 108: 95-99.

Mayer JLS, Stancato GC and Appezzato-da-Glória B (2010) Direct regeneration of protocorm-like bodies (PLBs) from leaf apices of Oncidium flexuosum Sims (Orchidaceae). Plant Cell, Tissue Organ Culture 103: 411-416

Menezes LC (2000) Orchids genus Cyrtopodium: Brazilian species. IBAMA, Brasília, 208p.

Mohanty P, Nongkling P, Das MC, Kumaria S and Tandon P (2013) Shortterm storage of alginate-encapsulated protocorm-like bodies of Dendrobium nobile Lindl.: an endangered medicinal orchid from North-east India. Biotechnology 3: 235-239.

Mulgund GS, Nataraja K, Malabadi RB and Kumar SV (2011) TDZ induced in vitro propagation of an epiphytic orchid Xenikophyton smeeanum (Reichb. f.) Research in Plant Biology 1: 7-15.

O'Brien TP. and McCully ME (1981) The study of plant structure: principles and selected methods. Termarcarphy Pty, Melburne, 352p.

Park SY, Murthy HN and Paek KY (2003) Protocorm-like body induction and subsequent plant regeneration from root tip cultures of Doritaenopsis. Plant Science 164: 919-923.

Peterson RL (1975) The initiation and development of root buds. In Torrey JG and Clarkson DT (eds) The development and function of roots. Academic Press, New York, p. 125-161.

Rodrigues LA, Paiva Neto VB, Boaretto AG, Oliveira JF, Torrezan MA, Lima SF and Otoni WC (2015) In vitro propagation of Cyrtopodium saintlegerianum rchb. f. (orchidaceae), a native orchid of the Brazilian savannah. Crop Breeding and Applied Biotechnology 15: 10-17.

Sánchez M (1988) Micropropagation of Cyrtopodium (Orchidaceae) through root-tip culture. Lindleyana 3: 93-96.

Silva JAT (2013) Cryopreservation of hybrid Cymbidium protocorm-like bodies by encapsulation-dehydration and vitrification. In Vitro Cellular and Developmental Biology Plant 49: 690-698.

Sujjaritthurakarn P and Kanchanapoom K (2011) Efficient direct protocorm-like bodies induction of dwarf Dendrobium using Thidiazuron. Notulae Scientia Biologicae 3: 88-92.

Wu IF, Chen JT and Chang WC (2004) Effect of auxins and cytokinins on embryo formation from root-derived callus of Oncidium 'Gower Ramsey'. Plant Cell, Tissue and Organ Culture 77: 107-109.

Zeng S, Wanga J, Wua K, Silva JAT, Zhanga J and Duan J (2013) In vitro propagation of Paphiopedilum hangianum Perner and Gruss. Scientia Horticulturae 151: 147-156. 